\title{
2-Hydroxyacyl-CoA Lyase 1
}

National Cancer Institute

\section{Source}

National Cancer Institute. 2-Hydroxyacyl-CoA Lyase 1. NCI Thesaurus. Code C122902.

2-hydroxyacyl-CoA lyase 1 (578 aa, $\sim 64 \mathrm{kDa}$ ) is encoded by the human HACL1 gene. This protein is involved in the metabolism of fatty acids. 